Recovery of toxic metal i ons fromwashing effl uent contai ni ng excess ami nopol ycar boxyl at e chel ant in sol ut i on

\begin{tabular}{|l|l|}
\hline 著者 & $\begin{array}{l}\text { Hasegawa H r oshi, Rahman I smai I M M, Nakano } \\
\text { Nasayoshi, Begum Zi nnat A., Egawa Yuj i , Naki } \\
\text { Ter uya, Fur usho Yoshi aki, M zut ani Sat oshi }\end{array}$ \\
\hline $\begin{array}{l}\text { j our nal or } \\
\text { publ i cat i on ti tl e }\end{array}$ & Wat er Resear ch \\
\hline vol une & 45 \\
\hline nunber & 16 \\
\hline page r ange & 4844 4854 \\
\hline year & $2011-10-15$ \\
\hline URL & ht t p: //hdl . handl e. net /2297/29197 \\
\hline
\end{tabular}




\section{Recovery of Toxic Metal Ions from Washing Effluent Containing Excess Aminopolycarboxylate Chelant in Solution}

Hiroshi Hasegawa, ${ }^{* 1}$ Ismail M. M. Rahman, ${ }^{* 1,2}$ Masayoshi Nakano, ${ }^{1}$ Zinnat A. Begum, ${ }^{1}$ Yuji Egawa, ${ }^{1}$ Teruya Maki, ${ }^{1}$ Yoshiaki Furusho, ${ }^{3}$ and Satoshi Mizutani ${ }^{4}$

${ }^{1}$ Graduate School of Natural Science and Technology, Kanazawa University, Kakuma, Kanazawa 920-1192, Japan

${ }^{2}$ Department of Chemistry, University of Chittagong, Chittagong 4331, Bangladesh

${ }^{3}$ GL Sciences, Inc., Nishishinjuku 6-22-1, Shinjuku, Tokyo 163-1130, Japan

${ }^{4}$ Graduate School of Engineering, Osaka City University, Sugimoto 3-3-138, Sumiyoshi-Ku, Osaka 558-8585, Japan

*Author(s) for correspondence.

E-mail: hhiroshi@t.kanazawa-u.ac.jp (H. Hasegawa); I.M.M.Rahman@gmail.com (I.M.M. Rahman).

Tel/ Fax: +81-76-234-4792 


\section{Abstract}

Aminopolycarboxylate chelants (APCs) are extremely useful for a variety of industrial applications, including the treatment of toxic metal-contaminated solid waste materials. Because non-toxic matrix elements compete with toxic metals for the binding sites of APCs, an excess of chelant is commonly added to ensure the adequate sequestration of toxic metal contaminants during waste treatment operations. The major environmental impacts of APCs are related to their ability to solubilize toxic heavy metals. If APCs are not sufficiently eliminated from the effluent, the aqueous transport of metals can occur through the introduction of APCs into the natural environment, increasing the magnitude of associated toxicity. Although several techniques that focus primarily on the degradation of APCs at the pre-release step have been proposed, methods that recycle not only the processed water, but also provide the option to recover and reuse the metals, might be economically feasible, considering the high costs involved due to the chelants used in metal ion sequestration. In this paper, we propose a separation process for the recovery of metals from effluents that contain an excess of APCs. Additionally, the option of recycling the processed water using a solid phase extraction (SPE) system with an ion-selective immobilized macrocyclic material, commonly known as a molecular recognition technology (MRT) gel, is presented. Simulated effluents containing $\mathrm{As}(\mathrm{V}), \mathrm{Cd}(\mathrm{II}), \mathrm{Cr}(\mathrm{III}), \mathrm{Pb}(\mathrm{II})$ or $\mathrm{Se}(\mathrm{IV})$ in the presence of APCs at molar ratios of 1:50 in $\mathrm{H}_{2} \mathrm{O}$ were studied with a flow rate of $0.2 \mathrm{~mL} \mathrm{~min}^{-1}$. The 'captured' ions in the SPE system were quantitatively eluted with $\mathrm{HNO}_{3}$. The effects of solution $\mathrm{pH}$, metalchelant stability constants and matrix elements were assessed. Better separation performance for the metals was achieved with the MRT-SPE compared to other SPE materials. Our proposed technique offers the advantage of a non-destructive separation of both metal ions and chelants compared to conventional treatment options for such effluents.

\section{Keywords}

Metal recovery; aminopolycarboxylate chelants; non-destructive separation; solid phase extraction; molecular recognition technology gel; washing effluents; wastewater treatment. 


\subsection{Introduction}

Aminopolycarboxylate chelants (APCs) are used in a variety of industrial processes, for example, metal plating or finishing, textile and paper manufacturing, industrial cleaning, and water softening (Conway et al., 1999; Nowack and VanBriesen, 2005). They have also been applied to the remediation of toxic metal-contaminated solid waste materials (Raghavan et al., 1991; Grasso, 1993; Abumaizar and Khan, 1996; Peters, 1999; Roundhill, 2001; Chang et al., 2007). Because ethylenediaminetetraacetic acid (EDTA) forms strong water-soluble chelant complexes with most toxic metals (Egli, 2001; Nowack and VanBriesen, 2005; Leštan et al., 2008), it has been utilized most often among the APCs.

Although APCs have received widespread acclaim for their excellent metal-binding capacities, the pre- and post-toxicities of APCs and related environmental consequences evoke many concerns (Rahman et al., 2011c). When APCs are released into aquatic environments, they may induce the remobilization of metal ions from soils and sediments into the water phase (Means et al., 1980; Nowack and VanBriesen, 2005), therefore extending the residence time of the metals. When APCs enter the environment, the exposure effects from APCs are likely to persist for a long time because of their poor photo-, chemo- and biodegradability (Means et al., 1980; Kari and Giger, 1995; Egli, 2001; Nowack, 2002; Nörtemann, 2005). Additionally, in most cases, the toxicity threshold values of APCs increase with metal complexation (Sillanpää and Oikari, 1996; Sorvari and Sillanpää, 1996; Sillanpää, 2005). APCs can also contribute to eutrophication by increasing the total nitrogen content and phosphate solubility in interstitial waters (Horstmann and Gelpke, 1991; Erel and Morgan, 1992; Hering and Morel, 2002). Legislative agencies have become more concerned about eco-environmental consequences due to the increasing use of APCs, and increasingly stringent environmental regulations have been imposed (Grundler et al., 2005; van Ginkel and Geerts, 2005). Therefore, the treatment of industrial effluents and metal-contaminated 
wastewaters from other sources containing APCs is a prerequisite before they can be safely discharged. The characteristics and concentrations of both the added chelant and metals in the source solutions are important factors to consider when determining methods of treatment (Juang et al., 1999). A degradation treatment of APCs in solution is considered when the concentration falls below $1 \mathrm{mM}$ (Juang and Wang, 2000b), and several methods have been proposed to obliterate and reduce the concentration of chelant in discharge waters (Krapfenbauer and Getoff, 1999; Muñoz and von Sonntag, 2000; Bucheli-Witschel and Egli, 2001; Rämö and Sillanpää, 2001; Sillanpää and Pirkanniemi, 2001; Pirkanniemi et al., 2007). However, the recovery and reuse of APCs and metals become the main concern for concentrations above $5 \mathrm{mM}$ in solution (Juang and Wang, 2000a) because the cost of chelants is a critical issue surrounding their use in metal ion sequestration (Kim and Ong, 1999; Lim et al., 2005; Leštan et al., 2008). An electrochemical reduction treatment followed by membrane separation (Juang and Wang, 2000a; Arévalo et al., 2002), a precipitation treatment with zero-valent metals (Lee and Marshall, 2002) or the addition of suitable reagents (e.g., $\mathrm{NaOH}, \mathrm{Ca}(\mathrm{OH})_{2}, \quad \mathrm{Na}_{2} \mathrm{~S}, \quad \mathrm{FeSO}_{4}, \mathrm{FeCl}_{3}, \mathrm{NaH}_{2} \mathrm{PO}_{4}, \mathrm{Na}_{2} \mathrm{HPO}_{4}, \quad$ or diethyldithiocarbamate) (Tünay and Kabdasli, 1994; Chang, 1995; Steele and Pichtel, 1998; Hong et al., 1999; Kim and Ong, 1999; Xie and Marshall, 2001; Di Palma et al., 2003; Lim et al., 2005) are potential techniques proposed for the recovery of metal ions from metal-chelant solutions. Operational problems, such as membrane fouling, membrane degradation, considerable costs or the inherent stability of metal-chelant complexes in solution, are some drawbacks of the proposed separation techniques (Kim and Ong, 1999; Di Palma et al., 2003; Lim et al., 2005). Most of the proposed separation techniques are also based on equimolar solutions of metals and APCs (Chang, 1995; Kim and Ong, 1999; Juang and Wang, 2000a), while washing effluents from metal-contaminated solid-waste treatment processes are often characterized by a large excess of free APCs in solution or APCs that are combined with 
other competitive ions in the waste (Di Palma et al., 2003; Leštan et al., 2008). A technique that ensures the effortless selective separation of metal ions and recycling of processed water, including APCs, may therefore be economically beneficial (Lim et al., 2005; Leštan et al., 2008).

The separation of metal ions from complex aqueous matrices using solid sorbent materials, a process known as solid phase extraction (SPE), has increased in popularity in recent years. SPE possesses the capability to interact with a variety of metal ions, and it has also been shown to interact with fairly specific selectivity to one particular ion of interest (Nickson et al., 1995; Hosten and Welz, 1999; Ghaedi et al., 2006; 2007; 2008; Rahman et al., 2011a; 2011b). SPE systems have not been used extensively for the separation of metal ions from wastewaters containing APCs because APCs compete with SPE materials for complexation of metal ions, which causes a remarkable decrease in the extraction efficiency (Hasegawa et al., 2010; 2011).

In this work, we propose a technique for the separation of toxic metal ions from synthetic effluents containing a large excess of APCs in solution. An ion-selective SPE system with immobilized macrocyclic material, commonly known as molecular recognition technology (MRT) gel (Bradshaw et al., 1988; Izatt et al., 1994; Izatt et al., 1995), was used to achieve a quantitative recovery of metal ions. Unique features of the proposed separation process include the nondestructive recovery of toxic metal ions from the excess APC-containing aqueous matrix and the one-step clean-up of the effluent with an option for recycling the processed water.

\subsection{Material and Methods}

\subsection{Instrumentation}

An inductively coupled plasma optical emission spectrometer (ICP-OES) (iCAP 6300, Thermo Fisher Scientific Inc., MA, USA), composed of an EMT duo quartz torch, glass 
spray chamber and concentric glass nebulizer, was used for the chemical analysis of metals. The operating conditions for the ICP-OES were as follows: the RF power at the torch was $1.15 \mathrm{~kW}$, the plasma gas flow was $12 \mathrm{~L} \mathrm{~min}^{-1}$, the auxiliary gas flow was $1 \mathrm{~L} \mathrm{~min}^{-1}$, the nebulizer gas flow was $0.5 \mathrm{~L} \mathrm{~min}^{-1}$, and the integration time was $30 \mathrm{~s}$.

A fully automated high-performance liquid chromatography (HPLC) system (TOSOH 8020, Tosoh, Tokyo, Japan) was used for the analysis of NTA, EDTA and DTPA. The HPLC system was composed of the following components: a DP-8020 pump, an AS-8021 auto sample injector, a CO-8020 column oven, a PD-8020 UV-VIS detector, PD-8020 data processing software, and TSK-gel ODS-80TM octadecylsilica columns $(4.6 \mathrm{~mm}$ i.d. $\times 250$ $\mathrm{mm}$ and $4.6 \mathrm{~mm}$ i.d. $\times 150 \mathrm{~mm}$ ). The mobile phase solution consisted of $5 \mathrm{mM}$ ammonium dihydrogenphosphate ( $\mathrm{pH} 2.4$ ) and was pumped at a flow rate of $0.5 \mathrm{~mL} \mathrm{~min}{ }^{-1}$ at $25^{\circ} \mathrm{C}$. The injection volume was $20 \mu \mathrm{L}$, and detection was performed at $254 \mathrm{~nm}$.

SPE was performed on a GL-SPE vacuum manifold kit (for 12 samples) (GL Sciences, Tokyo, Japan) combined with an air pump (CAS-1; AS ONE, Osaka, Japan). A Navi F-52 pH meter (Horiba Instruments, Kyoto, Japan) and a combination electrode were used for $\mathrm{pH}$ measurements.

A Barnstead 4-housing E-Pure water purification system (Barnstead/Thermolyne, Dubuque, IA, USA) was used to prepare deionized water, which is referred to as EPW hereafter.

\subsection{Materials}

Analytical grade commercial products were used without further purification. Stock solutions (10 mM) of $\mathrm{As}(\mathrm{V}), \mathrm{Cd}(\mathrm{II}), \mathrm{Cr}(\mathrm{III}), \mathrm{Pb}(\mathrm{II})$ and $\mathrm{Se}(\mathrm{IV})$ were prepared from sodium arsenate heptahydrate $\left(\mathrm{Na}_{2} \mathrm{HAsO}_{4} \cdot 7 \mathrm{H}_{2} \mathrm{O}\right.$; Kanto Chemical, Tokyo, Japan), cadmium (II) nitrate tetrahydrate $\left(\mathrm{Cd}\left(\mathrm{NO}_{3}\right)_{2} \cdot 4 \mathrm{H}_{2} \mathrm{O}\right.$; Wako Pure Chemical, Osaka, Japan), chromium (III)

nitrate nonahydrate $\left(\mathrm{Cr}\left(\mathrm{NO}_{3}\right)_{3} \cdot 9 \mathrm{H}_{2} \mathrm{O}\right.$; Wako Pure Chemical, Osaka, Japan), lead (II) nitrate 
$\left(\mathrm{Pb}\left(\mathrm{NO}_{3}\right)_{2}\right.$; Wako Pure Chemical, Osaka, Japan) and sodium selenite $\left(\mathrm{NaSeO}_{3}\right.$; Wako Pure Chemical, Osaka, Japan). Chelant stock solutions $(10 \mathrm{mM})$ were prepared from nitrilotriacetic acid $\left(\left(\mathrm{HOCOCH}_{2}\right)_{3} \mathrm{~N}\right.$, NTA; Kanto Chemical, Tokyo, Japan), disodium dihydrogen ethylenediamine tetraacetate dihydrate $\left(\mathrm{C}_{10} \mathrm{H}_{14} \mathrm{~N}_{2} \mathrm{Na}_{2} \mathrm{O}_{8} \cdot 2 \mathrm{H}_{2} \mathrm{O}\right.$, EDTA; Kanto Chemical, Tokyo, Japan) and diethylenetriamine-N,N,N',N', N','-pentaacetic acid $\left(\mathrm{C}_{14} \mathrm{H}_{23} \mathrm{~N}_{3} \mathrm{O}_{10}\right.$, DTPA; Dojindo Laboratories, Kumamoto, Japan). A multi-element solution (PlasmaCAL, SCP Science, Québec, Canada) containing 21 metals (Al, Ba, Be, Bi, Ca, Cd, $\mathrm{Co}, \mathrm{Cu}, \mathrm{Fe}, \mathrm{Ga}, \mathrm{In}, \mathrm{Mg}, \mathrm{Mn}, \mathrm{Ni}, \mathrm{Pb}, \mathrm{Sc}, \mathrm{Sr}, \mathrm{Ti}, \mathrm{V}, \mathrm{Y}$, and $\mathrm{Zn}$ ) in $5 \% \mathrm{HNO}_{3}$ was used to check the effects of diverse ions. Solutions of working standards ranging from $\mu \mathrm{M}$ to $\mathrm{mM}$ were prepared by dilution with EPW on a weight basis.

The experimental $\mathrm{pH}$ ranged from 4-9 and was adjusted using either $1 \mathrm{M} \mathrm{HCl}$ or $1 \mathrm{M}$ $\mathrm{NaOH}$. MES (2-( $\mathrm{N}$-morpholino) ethanesulfonic acid monohydrate, $\mathrm{C}_{6} \mathrm{H}_{13} \mathrm{NO}_{4} \mathrm{~S} \cdot \mathrm{H}_{2} \mathrm{O}$; SigmaAldrich, St. Louis, MO, USA), HEPES (N-2-Hydroxyethylpiperazine-N'-2-ethanesulfonic acid, $\mathrm{C}_{8} \mathrm{H}_{18} \mathrm{~N}_{2} \mathrm{O}_{4} \mathrm{~S} ; \quad$ Nacalai Tesque, Kyoto, Japan), and TAPS (NTris(hydroxymethyl)methyl-3-aminopropanesulfonic acid, $\mathrm{C}_{7} \mathrm{H}_{17} \mathrm{NO}_{6} \mathrm{~S} ; \mathrm{MP}$ Biomedicals, Solon, OH, USA) were used as buffer reagents for $\mathrm{pH} 4-6,7-8$ and 9, respectively. Aqueous solutions of $10 \mathrm{mM}$ chelating ligands in the appropriate buffer were spiked with $200 \mu \mathrm{M}$ of $\mathrm{As}(\mathrm{V}), \mathrm{Cd}(\mathrm{II}), \mathrm{Cr}(\mathrm{III}), \mathrm{Pb}(\mathrm{II})$ or $\mathrm{Se}(\mathrm{IV})$ to prepare the samples.

Different types of SPE materials were used, including an MRT gel, three chelating resins, and two ion exchange resins. The MRT gel type was AnaLig TE-01 (silica gel base containing crown ether functional groups; GL Sciences, Tokyo, Japan). The chelating resins were Chelex-100 (styrene divinylbenzene base containing iminodiacetic acid functional groups; Bio-Rad Laboratories, Hercules, CA, USA), NOBIAS Chelate PA-1 (hydrophilic methacrylate base containing polyamino-polycarboxylic acid functional groups; Hitachi High-Technologies, Tokyo, Japan), and NOBIAS Chelate PB-1 (divinylbenzene/ 
methacrylate polymer base containing polyamino-polycarboxylic acid functional groups; Hitachi High-Technologies, Tokyo, Japan). The ion exchange resins were NOBIAS Ion SA-1 (hydrophilic methacrylate base containing quaternized amine functional groups; Hitachi High-Technologies, Tokyo, Japan) and NOBIAS Ion SC-1 (hydrophilic methacrylate base containing sulfonic acid functional groups; Hitachi High-Technologies, Tokyo, Japan).

Low-density polyethylene bottles (Nalge Nunc, Rochester, NY, USA), perfluoroalkoxy (PFA) tubes and micropipette tips (Nichiryo, Tokyo, Japan) were used throughout the experiments. Before use, laboratory wares were first soaked in an alkaline detergent (Scat 20X-PF, Nacalai Tesque, Kyoto, Japan) overnight, and then in $4 \mathrm{M} \mathrm{HCl}$ overnight, followed by rinsing with EPW after each step.

Certified reference material (CRM) BCR-713 (effluent wastewater) from the European Commission Joint Research Centre, Institute of Reference Materials and Measurements (ECJRC-IRMM), along with spiked soil washing solution (i.e., natural arsenic-contaminated soil from Hokkaido, Japan that was treated with $10 \mathrm{mM}$ EDTA and spiked with a known amount of metal ions, followed by $6 \mathrm{~h}$ of shaking at room temperature) and spiked 'real' water samples (i.e., tap water from Kakuma, Kanazawa University, Kanazawa, Japan and water from Asano River, Kanazawa, Japan) were used for process validation. Cellulose membrane filters of $0.45 \mu \mathrm{m}$ pore size (Advantec, Tokyo, Japan) were used for the pre-separation step filtration treatment of the soil washing solution and the 'real' water samples.

\subsection{Experimental setup}

SPE materials were packed into $5 \mathrm{~mL}$ columns, and the columns were cleaned with $1 \mathrm{M}$ $\mathrm{HNO}_{3}(8 \mathrm{~mL})$ and EPW $(6 \mathrm{~mL})$. MES, HEPES or TAPS buffer solution $(32 \sim 40 \mathrm{~mL}, 2 \mathrm{~mL}$ each loading) was allowed to flow through the column to ensure desired $\mathrm{pH}$ conditions from 4 to 9 in the SPE columns. 
A total of $4 \mathrm{~mL}$ sample solution with $\mathrm{pH}$ already pre-adjusted with $0.1 \mathrm{M}$ buffer solution (MES, HEPES or TAPS, whichever was appropriate) was passed through the SPE column at a controlled flow rate of $0.2 \mathrm{~mL} \mathrm{~min}^{-1}$, and the column effluent was collected. The next step involved washing the column with EPW to remove the analyte fraction that was not retained. The final step was the elution of the 'captured' analyte with $\mathrm{HNO}_{3}(1$ and $6 \mathrm{M})$ from the SPE system. The metal concentrations in the sample, column effluent, wash effluent and elution effluent were measured using the ICP-OES.

The terms extraction and recovery were used to explain the separation performance of the SPE systems and were calculated from the analyte concentrations in the column effluent, wash effluent and elution effluent. The extraction ratio (\%) of each column for individual metal species was calculated by comparing the numbers of moles of analyte in the elution effluent with the cumulative number of moles of analyte present in all the effluents. The cumulative number of moles of analyte recovered from all fractions (i.e., column effluent, wash effluent and elution effluent) was compared with the numbers of moles of analyte in the solution that was loaded onto the column to calculate the recovery ratio (\%).

Three replicates for each of the experiments were performed, and the average values were reported.

The workflow sequence for the separation of metal ions using SPE columns followed by ICP-OES determination is shown schematically in Fig. 1.

\subsection{Results and discussion}

\subsection{Comparative evaluation of MRT-SPE and other commercial SPE materials}

\subsubsection{Extraction and recovery behavior}

Aqueous solutions containing toxic metal ions and APCs (NTA, EDTA and DTPA) in 1:50 molar ratios were treated with the MRT-SPE (AnaLig TE-01) and other commercial SPE materials (Chelex-100, NOBIAS Chelate PA-1, NOBIAS Chelate PB-1, NOBIAS Ion 
SA-1, and NOBIAS Ion SC-1) to compare the separation efficiencies at optimized conditions. As shown in Fig. 2, when we evaluated the metal separation performance of the SPE columns with or without APCs, we concluded that excess chelant in solution resulted in considerable performance variations of the SPEs. It was also apparent that the MRT-SPE ensured quantitative extraction of the toxic metal ions from the aqueous solution with or without APCs. However, an exception should be noted for the aqueous systems containing NTA and $\mathrm{Pb}(\mathrm{II})$, which exhibited an extraction rate below $77 \%$ for all of the SPE systems. The MRTSPE demonstrated superior extraction efficiency for EDTA-rich metal-fortified aqueous solutions when compared with other SPE systems, where the extraction rates were $\leq 60 \%$. Separation of $\mathrm{Cr}(\mathrm{III})$ or $\mathrm{Pb}$ (II) from DTPA-rich aqueous solutions was quantitative for all the SPE systems, and aqueous systems with $\mathrm{Pb}(\mathrm{II})$ displayed similar behavior, even when no chelant was present in solution. The complete recovery of the metal ions that were 'captured' in the SPE columns was achieved with the MRT-SPE, while exceptions for As(V)- and Cr(II)-spiked solutions without chelant were observed for some of the commercial SPE materials other than MRT-SPE.

As(V) and Se(IV) have no known affinity for the APCs used here. However, those ions were simultaneously extracted with the APCs in solution, which subsequently reduced the extraction efficiencies of the SPEs (Fig. 2). These limitations were minimized with the use of MRT-SPE because the quantitative maximum extraction followed by recovery was achieved, compared with the other SPE systems.

\subsubsection{Effect of the metal-chelant stability constant}

APCs (i.e., NTA, EDTA or DTPA) form water-soluble metal complexes of high thermodynamic stability (Lim et al., 2005) of varying metal-chelant stability constants $\left(K_{\mathrm{ML}}\right)$ with $\mathrm{Cd}(\mathrm{II}), \mathrm{Cr}(\mathrm{III})$ or $\mathrm{Pb}(\mathrm{II})$ (Table 1), which may influence the separation performance of the SPE materials. The effect of the metal-chelant complexes' conditional stability constants 
$\left(K^{\prime}{ }_{M L}\right.$, at $\left.\mathrm{pH} 7\right)$ on the performance of MRT-SPE and other commercial SPE materials was studied for the extraction of $\mathrm{Cd}(\mathrm{II}), \mathrm{Cr}(\mathrm{III})$ or $\mathrm{Pb}(\mathrm{II})$ ions from chelant-rich, metal-spiked aqueous system (Fig. 3). AnaLig TE-01 demonstrated better effectiveness than the other SPE materials (i.e., Chelex-100, NOBIAS Chelate PA-1, NOBIAS Chelate PB-1, NOBIAS Ion SA-1, NOBIAS Ion SC-1) for Cd(II), $\mathrm{Cr}(\mathrm{III})$ or $\mathrm{Pb}(\mathrm{II})$ separation from EDTA-rich aqueous solutions. Comparable separation performances for $\mathrm{Cd}(\mathrm{II})$ or $\mathrm{Pb}(\mathrm{II})$ were observed for excess DTPA-containing solutions.

The $\mathrm{Pb}(\mathrm{II})$ extraction rate with MRT-SPE from NTA-rich mixtures was only $57.5 \pm 1.9 \%$, but none of the SPE columns were capable of ensuring its quantitative extraction. It is likely that the separation between metals and chelants (i.e., the extraction of metal) will be easier when the stability constant of the metal-chelant complex is low. The $K^{\prime}{ }_{\mathrm{ML}}$ (at $\mathrm{pH} 7$ ) of the $\mathrm{Pb}(\mathrm{II})-\mathrm{NTA}$ complex (8.82) in the aqueous matrix was lower than that for EDTA and DTPA, and the quantitative maximum $\mathrm{Pb}(\mathrm{II})$ extraction rate was expected from NTA-containing solutions as it was obtained for EDTA and DTPA. However, Pb(II) oxide has a propensity to precipitate at neutral $\mathrm{pH}$. Such precipitation is facilitated as a result of the lower affinity between NTA and $\mathrm{Pb}$, which has a significant effect on the extraction capacity of the SPE system. Although the $K^{\prime}{ }_{\text {ML }}$ of Cd(II)-NTA complex (7.10) was also comparatively low, $\mathrm{Cd}(\mathrm{II})$ ions remain soluble in the aqueous matrix at $\mathrm{pH} 7$ and have no such effect on the extraction performance.

In general, we note that MRT-SPE can effectively be used to separate metal ions from the chelant-rich aqueous solutions for metal-chelant stability constants up to 18.8 , which is the $K_{\mathrm{ML}}$ value for $\mathrm{Pb}(\mathrm{II})$-DTPA, with exception of the behavior of $\mathrm{Pb}(\mathrm{II})$ with NTA. The MRTSPE appeared as the solitary potential option for the separation of toxic metal ions from aqueous solutions containing an excess of EDTA, which is the most widely used APC for metal-contaminated waste treatment. 


\subsection{Effect of variables on the performance of MRT-SPE}

\subsection{1 $\mathrm{pH}$}

The separation performance of the AnaLig TE-01 SPE column was studied as a function of $\mathrm{pH}$ and was described in terms of extraction and recovery rate (Fig. 4). The experimental conditions utilized EDTA, considering its frequent use among the APCs. Therefore, the study was restricted to the $\mathrm{pH}$ range from 4-9 because of the insufficient solubility of EDTA at very low $\mathrm{pH}$ in aqueous media (Ueno et al., 1992). The increasing solubility of silica gel with increasing pH (Vogelsberger et al., 1992), which may dissolve the silica gel base support of AnaLig TE-01 column, was also a concern. Nearly similar extraction patterns for As(V) or Se(IV) were observed with or without EDTA in solution, which established that the excess chelant in the aqueous system had no significant influence on the solubility or separation aptitude of those metals. However, a significant drop in the extraction rate of As(V) or Se(IV) above a $\mathrm{pH}$ of 8 was observed, which may have been due to increased concentrations of the competitive ions $\left(\mathrm{OH}^{-}\right.$or $\left.\mathrm{HL}^{3-}\right)$ in the system. An extraction rate of $\geq 98 \%$ for $\mathrm{Cd}(\mathrm{II}), \mathrm{Cr}(\mathrm{III})$ and $\mathrm{Pb}(\mathrm{II})$ from $\mathrm{pH} 5$ to 7 was attained from metal-fortified solutions containing an excess of chelant, while the changes in the recovery rates were insignificant in terms of $\mathrm{pH}$. The decrease in the extraction rate at $\mathrm{pH}<5$ or $>7$ can be attributed either to an excess of $\mathrm{H}^{+}$ions in the acidic region or $\mathrm{OH}^{-} / \mathrm{HL}^{3-}$ ions in the basic region, respectively. Subsequent experiments with the MRT-SPE column were conducted at $\mathrm{pH} 7$ to minimize any possible effects from the competitive ions.

\subsubsection{Sample loading flow rate}

The loading flow rates of metal-fortified sample solutions have a significant influence on metal retention rates in SPE columns (Bag et al., 1998). The effects of sample loading flow rates were studied in the range of $0.2-5 \mathrm{~mL} \mathrm{~min}^{-1}$. A gradual decrease in retention capacities of the MRT-SPE column was observed with increasing flow rates above $0.25 \mathrm{~mL} \mathrm{~min}^{-1}$ (Fig. 
5). A constant retaining capability of the MRT-SPE column at the initial loading period is indicated by such behavior; therefore, a flow rate of $0.2 \mathrm{~mL} \mathrm{~min}{ }^{-1}$ was applied for subsequent experiments.

\subsubsection{Eluent}

Eluent selected for a particular separation process should be capable of extracting the analyte, thereby facilitating its quantitative determination (Chen et al., 2009). Analytes retained in the MRT-SPE column were eluted with $\mathrm{HNO}_{3}(4 \mathrm{~mL})$ of varying concentrations (0.1-6 M), which all displayed constant recovery rates for eluent concentrations above $0.5 \mathrm{M}$ (Fig. 6). However, IBC Advanced Technologies (2007) recommended the use of $\geq 5 \mathrm{M}$ acids for the elution of bound ions in the TE-01 SPE column. Hence, a combination of $1 \mathrm{M} \mathrm{HNO}_{3}$ (2 $\mathrm{mL})$ and $6 \mathrm{M} \mathrm{HNO}_{3}(1 \mathrm{~mL})$ was selected as the eluent for subsequent experiments to ensure the complete elution of the analyte when treated with TE- 01.

\subsection{Effect of diverse metal ions}

The interference caused by complexing species results in significant problems towards the quantitative extraction of analytes (Prabhakaran and Subramanian, 2003). To examine the separation efficiency of MRT-SPE in the presence of various interfering metal ions, studies were performed using PlasmaCAL multi-element metal ion solutions spiked with the target metal ions and APCs. EDTA was used as the representative APC because EDTA has most often been utilized among the APCs, owing to its capacity to form water-soluble chelant complexes with most toxic metals (Egli, 2001; Nowack and VanBriesen, 2005; Leštan et al., 2008). The metal-to-chelant ratio was maintained at 1:50, and the final solutions were allowed to equilibrate for $24 \mathrm{~h}$ before analysis. The extraction and recovery rates demonstrated the superior ion selective separation performance of the MRT-SPE in the presence of large concentrations of matrix components (Table 2). 


\subsection{Retention capacity of the MRT-SPE}

The stability of the SPE system during the separation process can be determined from its retention capacity, which is calculated from the breakthrough volume (i.e., the volume of sample that causes the target analyte to be eluted from the SPE material) and the analyte concentration ( $\mathrm{Yu}$ et al., 2003). Metal-spiked sample solutions were passed through the MRT-SPE column, eluted and subjected to ICP-OES analysis to estimate the retention capacity expressed in terms of mmol of analyte captured in one gram of SPE material. The retention capacities of the MRT-SPE $\left(\mathrm{mmol} \mathrm{g}^{-1}\right)$ at $\mathrm{pH} 7$ were as follows: $0.44 \pm 0.04$ for $\mathrm{As}(\mathrm{V}), 0.41 \pm 0.06$ for $\mathrm{Cd}(\mathrm{II}), 0.05 \pm 0.02$ for $\mathrm{Cr}(\mathrm{III}), 0.48 \pm 0.06$ for $\mathrm{Pb}(\mathrm{II})$, and $0.34 \pm 0.05$ for $\mathrm{Se}(\mathrm{IV})$. The matrix was $\mathrm{H}_{2} \mathrm{O}$, the flow rate was $0.2 \mathrm{~mL} \mathrm{~min}^{-1}$, and the elution solution consisted of $2 \mathrm{~mL}$ of $1 \mathrm{M} \mathrm{HNO}_{3}, 1 \mathrm{~mL}$ of $6 \mathrm{M} \mathrm{HNO}_{3}$, and $1 \mathrm{~mL}$ of EPW.

\subsection{Regeneration ability of the MRT-SPE}

The regeneration ability of the MRT-SPE was investigated with sample solutions spiked with $200 \mu \mathrm{M}$ of $\mathrm{As}(\mathrm{V})$ or $\mathrm{Pb}(\mathrm{II})$ ions and $10 \mathrm{mM}$ of EDTA in aqueous matrix. Again, the flow rate was $0.2 \mathrm{~mL} \mathrm{~min}^{-1}$, and the elution solution contained $2 \mathrm{~mL}$ of $1 \mathrm{M} \mathrm{HNO}_{3}, 1 \mathrm{~mL}$ of $6 \mathrm{M} \mathrm{HNO}_{3}$, and $1 \mathrm{~mL}$ of EPW. The extraction rates of the fresh column $(\mathrm{As}(\mathrm{V}): 99.0 \pm 0.1$; $\mathrm{Pb}$ (II): $100 \pm 0.1$ ) and after 100 cycles (As(V): 97.2 $\pm 4.1 ; \mathrm{Pb}(\mathrm{II}): 98.4 \pm 0.3$ ) were evaluated to conclude that more than 100 loading and elution cycles could be performed using MRT-SPE without any loss of analytical performance.

\subsection{Accuracy and applications}

\subsubsection{Recovery of metals from certified reference material}

EC-JRC-IRMM CRM, namely BCR-713 (effluent wastewater), spiked with $10 \mu \mathrm{M}$ of EDTA ( $\mathrm{pH}$ maintained at 7 with HEPES buffer), was used to evaluate the accuracy of the proposed separation process (Table 3 ). The recovery rates for $\mathrm{As}(\mathrm{V})$ and $\mathrm{Cd}(\mathrm{II})$ were 89.7 and $101.4 \%$, respectively, while $\mathrm{Cr}(\mathrm{III}), \mathrm{Pb}(\mathrm{II})$ or $\mathrm{Se}(\mathrm{IV})$ were not detected. 


\subsubsection{Recovery of metals from 'real' water samples and soil washing effluent}

The proposed separation process was applied to the analysis of local natural water samples (i.e., both tap water and river water) and soil washing effluent. The samples were spiked with known amounts of $\mathrm{As}(\mathrm{V}), \mathrm{Cd}(\mathrm{II}), \mathrm{Cr}(\mathrm{III}), \mathrm{Pb}(\mathrm{II})$ or $\mathrm{Se}(\mathrm{IV})$ and $10 \mathrm{mM}$ of EDTA, followed by MRT-SPE separation and ICP-OES analysis (Table 4). Recoveries at varying rates $(99-101 \%$ for $\mathrm{As}(\mathrm{V}), 84-102 \%$ for $\mathrm{Cd}(\mathrm{II}), 101-102 \%$ for $\mathrm{Cr}(\mathrm{III}), 98-100 \%$ for $\mathrm{Pb}(\mathrm{II})$, and $88-100 \%$ for $\mathrm{Se}(\mathrm{IV})$ ) from metal-spiked excess chelant-containing solutions were observed.

\subsection{Conclusion}

The recoveries of $\mathrm{As}(\mathrm{V}), \mathrm{Cd}(\mathrm{II}), \mathrm{Cr}(\mathrm{III}), \mathrm{Pb}(\mathrm{II})$ and $\mathrm{Se}(\mathrm{IV})$ from simulated washing effluents containing an excess of APCs (i.e., NTA, EDTA or DTPA) was accomplished with an ion-selective immobilized macrocyclic material, commonly known as MRT gel. The MRT-SPE system showed optimum separation performance in the $\mathrm{pH}$ range of 5 to 7 . Quantitative extraction occurred using a sample loading flow rate of $0.2 \mathrm{~mL} \mathrm{~min}^{-1}$, and the 'captured' metal ions were eluted with a mixture of 1 and $6 \mathrm{M} \mathrm{HNO}_{3}$. The MRT-SPE was stable during operation and enabled more than 100 loading and elution cycles to be performed without any loss of analytical performance. The non-destructive treatment of chelant-enriched metal-contaminated effluent with the subsequent option to recycle the processed water and metal ions are the major focal points of the proposed separation process.

\section{Acknowledgement}

This research was partially supported by Grants-in-Aid for Scientific Research (K22042) from the Ministry of the Environment, Japan. 


\section{References}

Abumaizar, R., Khan, L.I., 1996. Laboratory investigation of heavy metal removal by soil washing. J. Air Waste Manag. Assoc. 46, 765-768.

Arévalo, E.F., Stichnothe, H., Thöming, J., Calmano, W., 2002. Evaluation of a leaching process coupled with regeneration/recycling of the extractant for treatment of heavy metal contaminated solids. Environ. Technol. 23, 571-581.

Bag, H., Lale, M., Türker, A.R., 1998. Determination of iron and nickel by flame atomic absorption spectrophotometry after preconcentration on Saccharomyces cerevisiae immobilized sepiolite. Talanta 47, 689-696.

Bradshaw, J.S., Bruening, R.L., Krakowiak, K.E., Tarbet, B.J., Bruening, M.L., Izatt, R.M., Christensen, J.J., 1988. Preparation of silica gel-bound macrocycles and their cationbinding properties. J. Chem. Soc. Chem. Comm., 812-814.

Bucheli-Witschel, M., Egli, T., 2001. Environmental fate and microbial degradation of aminopolycarboxylic acids. FEMS Microbiol. Rev. 25, 69-106.

Chang, F.-C., Lo, S.-L., Ko, C.-H., 2007. Recovery of copper and chelating agents from sludge extracting solutions. Sep. Purif. Technol. 53, 49-56.

Chang, L.-Y., 1995. A waste minimization study of a chelated copper complex in wastewater - Treatability and process analysis. Waste Manag. 15, 209-220.

Chen, D., Huang, C., He, M., Hu, B., 2009. Separation and preconcentration of inorganic arsenic species in natural water samples with 3-(2-aminoethylamino) propyltrimethoxysilane modified ordered mesoporous silica micro-column and their determination by inductively coupled plasma optical emission spectrometry. J. Hazard. Mater. 164, 1146-1151.

Conway, M., Holoman, S., Jones, L., Leenhouts, R., Williamson, G., 1999. Selecting and using chelating agents. Chem. Eng. 106, 86-90. 
Di Palma, L., Ferrantelli, P., Merli, C., Biancifiori, F., 2003. Recovery of EDTA and metal precipitation from soil flushing solutions. J. Hazard. Mater. 103, 153-168.

Egli, T., 2001. Biodegradation of metal-complexing aminopolycarboxylic acids. J. Biosci. Bioeng. 92, 89-97.

Erel, Y., Morgan, J.J., 1992. The relationships between rock-derived lead and iron in natural waters. Geochim. Cosmochim. Ac. 56, 4157-4167.

Ghaedi, M., Asadpour, E., Vafaie, A., 2006. Sensitized spectrophotometric determination of $\mathrm{Cr}$ (III) ion for speciation of chromium ion in surfactant media using $\alpha$-benzoin oxime. Spectrochim. Acta A 63, 182-188.

Ghaedi, M., Ahmadi, F., Shokrollahi, A., 2007. Simultaneous preconcentration and determination of copper, nickel, cobalt and lead ions content by flame atomic absorption spectrometry. J. Hazard. Mater. 142, 272-278.

Ghaedi, M., Shokrollahi, A., Kianfar, A.H., Mirsadeghi, A.S., Pourfarokhi, A., Soylak, M., 2008. The determination of some heavy metals in food samples by flame atomic absorption spectrometry after their separation-preconcentration on bis salicyl aldehyde, 1,3 propan diimine (BSPDI) loaded on activated carbon. J. Hazard. Mater. $154,128-134$.

Grasso, D., 1993. Hazardous Waste Site Remediation: Source Control, Lewis Publishers, Boca Raton, FL.

Grundler, O.J., van der Steen, A.T.M., Wilmot, J., 2005. Overview of the European risk assessment on EDTA. In: Nowack, B., VanBriesen, J.M. (Eds.), Biogeochemistry of Chelating Agents. American Chemical Society, Washington, DC, pp. 336-347.

Hasegawa, H., Rahman, I.M.M., Kinoshita, S., Maki, T., Furusho, Y., 2010. Non-destructive separation of metal ions from wastewater containing excess aminopolycarboxylate 
chelant in solution with an ion-selective immobilized macrocyclic material. Chemosphere 79, 193-198.

Hasegawa, H., Rahman, I.M.M., Kinoshita, S., Maki, T., Furusho, Y., 2011. Separation of dissolved iron from the aqueous system with excess ligand. Chemosphere 82, 11611167.

Hering, J.G., Morel, F.M.M., 2002. Kinetics of trace metal complexation: role of alkalineearth metals. Environ. Sci. Technol. 22, 1469-1478.

Hong, P.K.A., Li, C., Banerji, S.K., Regmi, T., 1999. Extraction, recovery, and biostability of EDTA for remediation of heavy metal-contaminated soil. J. Soil Contam. 8, 81-103.

Horstmann, U., Gelpke, N., 1991. Algal growth stimulation by chelatisation risks associated with complexants in P-free washing agents. Rev. Intl. Oceanogr. Med. 260, 101-104.

Hosten, E., Welz, B., 1999. Evaluation of an immobilised macrocyclic material for on-line column preconcentration and separation of cadmium, copper and lead for electrothermal atomic absorption spectrometry. Anal. Chim. Acta 392, 55-65.

IBC Advanced Technologies, 2007. AnaLig® Data Sheet: TE-01 and TE-02, IBC Advanced Technologies, Inc., American Fork, UT.

Izatt, R.M., Bradshaw, J.S., Bruening, R.L., Bruening, M.L., 1994. Solid phase extraction of ions of analytical interest using molecular recognition technology. Am. Lab. 26, 28C$28 \mathrm{M}$

Izatt, R.M., Bradshaw, J.S., Bruening, R.L., Tarbet, B.J., Bruening, M.L., 1995. Solid phase extraction of ions using molecular recognition technology. Pure Appl. Chem. 67, $1069-1074$.

Juang, R.S., Wang, S.W., Lin, L.C., 1999. Simultaneous recovery of EDTA and lead(II) from their chelated solutions using a cation exchange membrane. J. Membr. Sci. 160, 225233. 
Juang, R.S., Wang, S.W., 2000a. Metal recovery and EDTA recycling from simulated washing effluents of metal-contaminated soils. Water Res. 34, 3795-3803.

Juang, R.S., Wang, S.W., 2000b. Electrolytic recovery of binary metals and EDTA from strong complexed solutions. Water Res. 34, 3179-3185.

Kari, F.G., Giger, W., 1995. Modeling the photochemical degradation of ethylenediaminetetraacetate in the river Glatt. Environ. Sci. Technol. 29, 2814-2827.

Kim, C., Ong, S.-K., 1999. Recycling of lead-contaminated EDTA wastewater. J. Hazard. Mater. 69, 273-286.

Krapfenbauer, K., Getoff, N., 1999. Comparative studies of photo- and radiation-induced degradation of aqueous EDTA. Synergistic effects of oxygen, ozone and $\mathrm{TiO}_{2}$ (acronym: CoPhoRaDe/EDTA). Radiat. Phys. Chem. 55, 385-393.

Lee, C.C., Marshall, W.D., 2002. Recycling of complexometric extractants to remediate a soil contaminated with heavy metals. J. Environ. Monit. 4, 325-329.

Leštan, D., Luo, C.L., Li, X.D., 2008. The use of chelating agents in the remediation of metal-contaminated soils: A review. Environ. Pollut. 153, 3-13.

Lim, T.T., Chui, P.C., Goh, K.H., 2005. Process evaluation for optimization of EDTA use and recovery for heavy metal removal from a contaminated soil. Chemosphere 58, $1031-1040$.

Martell, A.E., Smith, R.M., Motekaitis, R.J., 2004. NIST Standard Reference Database 46: NIST Critically Selected Stability Constants of Metal Complexes Database (Version 8.0 For Windows), Texas A\&M University, College Station, TX.

Means, J.L., Kucak, T., Crerar, D.A., 1980. Relative degradation rates of NTA, EDTA and DTPA and environmental implications. Environ. Pollut. B 1, 45-60. 
Muñoz, F., von Sonntag, C., 2000. The reactions of ozone with tertiary amines including the complexing agents nitrilotriacetic acid (NTA) and ethylenediaminetetraacetic acid (EDTA) in aqueous solution. J. Chem. Soc. Perk. T. 2, 2029-2033.

Nickson, R.A., Hill, S.J., Worsfold, P.J., 1995. Analytical perspective. Solid phase techniques for the preconcentration of trace metals from natural waters. Anal. Proc. 32, 387-395.

Nörtemann, B., 2005. Biodegradation of chelating agents: EDTA, DTPA, PDTA, NTA, and EDDS. In: Nowack, B., VanBriesen, J.M. (Eds.), Biogeochemistry of Chelating Agents. American Chemical Society, Washington, DC, pp. 150-170.

Nowack, B., 2002. Environmental chemistry of aminopolycarboxylate chelating agents. Environ. Sci. Technol. 36, 4009-4016.

Nowack, B., VanBriesen, J.M., 2005. Chelating agents in the environment. In: Nowack, B., VanBriesen, J.M. (Eds.), Biogeochemistry of Chelating Agents. American Chemical Society, Washington, DC, pp. 1-18.

Peters, R.W., 1999. Chelant extraction of heavy metals from contaminated soils. J. Hazard. Mater. 66, 151-210.

Pirkanniemi, K., Metsärinne, S., Sillanpää, M., 2007. Degradation of EDTA and novel complexing agents in pulp and paper mill process and waste waters by Fenton's reagent. J. Hazard. Mater. 147, 556-561.

Prabhakaran, D., Subramanian, M.S., 2003. Selective extraction and sequential separation of actinide and transition ions using AXAD-16-BTBED polymeric sorbent. React. Funct. Polym. 57, 147-155.

Raghavan, R., Coles, E., Dietz, D., 1991. Cleaning excavated soil using extraction agents: A state-of-the-art review. J. Hazard. Mater. 26, 81-87.

Rahman, I.M.M., Begum, Z.A., Nakano, M., Furusho, Y., Maki, T., Hasegawa, H., 2011 a. Selective separation of arsenic species from aqueous solutions with immobilized 
macrocyclic material containing solid phase extraction columns. Chemosphere 82, $549-556$.

Rahman, I.M.M., Furusho, Y., Begum, Z.A., Izatt, N., Bruening, R., Sabarudin, A., Hasegawa, H., 2011b. Separation of lead from high matrix electroless nickel plating waste solution using an ion-selective immobilized macrocycle system. Microchem. J. $98,103-108$.

Rahman, I.M.M., Hossain, M.M., Begum, Z.A., Rahman, M.A., Hasegawa, H., 2011c. Ecoenvironmental consequences associated with chelant-assisted phytoremediation of metal-contaminated soil. In: Golubev, I.A. (Ed.), Handbook of Phytoremediation. Nova Science Publishers, Inc., New York, pp. 709-722.

Rämö, J., Sillanpää, M., 2001. Degradation of EDTA by hydrogen peroxide in alkaline conditions. J. Clean. Prod. 9, 191-195.

Roundhill, D.M., 2001. Extraction of Metals from Soils and Waters, Kluwer Academic/Plenum Publishers, New York.

Sillanpää, M., Oikari, A., 1996. Assessing the impact of complexation by EDTA and DTPA on heavy metal toxicity using microtox bioassay. Chemosphere 32, 1485-1497.

Sillanpää, M., Pirkanniemi, K., 2001. Recent developments in chelate degradation. Environ. Technol. 22, 791-801.

Sillanpää, M.E.T., 2005. Distribution and fate of chelating agents in the environment. In: Nowack, B., VanBriesen, J.M. (Eds.), Biogeochemistry of Chelating Agents. American Chemical Society, Washington, DC, pp. 226-233.

Sorvari, J., Sillanpää, M., 1996. Influence of metal complex formation on heavy metal and free EDTA and DTPA acute toxicity determined by Daphnia magna. Chemosphere $33,1119-1127$. 
Steele, M.C., Pichtel, J., 1998. Ex-situ remediation of a metal-contaminated superfund soil using selective extractants. J. Environ. Eng.-ASCE 124, 639-645.

Tünay, O., Kabdasli, N.I., 1994. Hydroxide precipitation of complexed metals. Water Res. 28, $2117-2124$.

Ueno, K., Imamura, T., Cheng, K.L., 1992. Handbook of Organic Analytical Reagents, CRC Press, Boca Raton, FL.

van Ginkel, C.G., Geerts, R., 2005. Full-Scale biological treatment of industrial effluents containing EDTA. In: Nowack, B., VanBriesen, J.M. (Eds.), Biogeochemistry of Chelating Agents. American Chemical Society, Washington, DC, pp. 195-203.

Vogelsberger, W., Seidel, A., Rudakoff, G., 1992. Solubility of silica gel in water. J. Chem. Soc. Faraday T. 88, 473-476.

Xie, T., Marshall, W.D., 2001. Approaches to soil remediation by complexometric extraction of metal contaminants with regeneration of reagents. J. Environ. Monit. 3, 411-416.

Yu, C.H., Cai, Q.T., Guo, Z.X., Yang, Z.G., Khoo, S.B., 2003. Inductively coupled plasma mass spectrometry study of the retention behavior of arsenic species on various solid phase extraction cartridges and its application in arsenic speciation. Spectrochim. Acta B 58, 1335-1349. 
Table 1: Acid dissociation constants $\left(\mathrm{p} K_{\mathrm{a}}\right)$, stability constants $\left(K_{\mathrm{ML}}\right)$ and conditional stability constants $\left(K^{\prime}{ }_{M L}\right)$ of metal-ligand complexes at $25^{\circ} \mathrm{C}(\mu=0.1)^{\mathrm{a}}$.

\begin{tabular}{|c|c|c|c|c|c|c|c|c|c|c|c|}
\hline APCs & $\mathrm{p} K_{\mathrm{a}}$ & & & & & $K_{\mathrm{ML}}$ & & & $K^{\prime}{ }_{\mathrm{ML}}$ & $\mathrm{pH}^{\prime}$ & \\
\hline & $\mathrm{p} K_{\mathrm{a} 1}$ & $\mathrm{p} K_{\mathrm{a} 2}$ & $\mathrm{p} K_{\mathrm{a} 3}$ & $\mathrm{p} K_{\mathrm{a} 4}$ & $\mathrm{p} K_{\mathrm{a} 5}$ & $\mathrm{Cd}^{2+}$ & $\mathrm{Cr}^{3+}$ & $\mathrm{Pb}^{2+}$ & $\mathrm{Cd}^{2+}$ & $\mathrm{Cr}^{3+}$ & $\mathrm{Pb}^{2+}$ \\
\hline NTA & 1.81 & 2.52 & 9.66 & & & 9.76 & $\mathrm{NA}^{\mathrm{b}}$ & 11.48 & 7.10 & - & 8.82 \\
\hline EDTA & 2.00 & 2.69 & 6.13 & 10.19 & & 16.5 & 23.4 & 18.0 & 13.3 & 20.2 & 14.8 \\
\hline DTPA & 2.0 & 2.70 & 4.28 & 8.60 & 10.50 & 19.0 & $\mathrm{NA}^{\mathrm{b}}$ & 18.8 & 15.5 & - & 15.3 \\
\hline
\end{tabular}

${ }^{\mathrm{a}}$ Martell et al. (2004).

${ }^{\mathrm{b}} \mathrm{NA}=$ Not available. Data not available in the critically selected NIST database 
Table 2. Separation performance of the MRT-SPE column in the presence of various interfering metal species in the matrix ${ }^{\mathrm{a}}$.

\begin{tabular}{lll}
\hline Species & Extraction (\%) & Recovery (\%) \\
\hline $\mathrm{As}(\mathrm{V})$ & $99.6 \pm 3.4$ & $100 \pm 4.2$ \\
$\mathrm{Cd}(\mathrm{II})$ & $101 \pm 4.7$ & $100 \pm 1.6$ \\
$\mathrm{Cr}(\mathrm{III})$ & $98.7 \pm 3.9$ & $99.4 \pm 1.1$ \\
$\mathrm{~Pb}(\mathrm{II})$ & $100 \pm 2.5$ & $97.8 \pm 3.4$ \\
$\mathrm{Se}(\mathrm{IV})$ & $97.7 \pm 3.6$ & $102 \pm 2.1$
\end{tabular}

\footnotetext{
${ }^{\mathrm{a}}$ Sample solutions were composed of $200 \mu \mathrm{M} \mathrm{As}(\mathrm{V}), \mathrm{Cd}(\mathrm{II}), \mathrm{Cr}(\mathrm{III}), \mathrm{Pb}(\mathrm{II})$, or $\mathrm{Se}(\mathrm{IV})$. The chelant was 10 mM EDTA, and the matrix was $\mathrm{H}_{2} \mathrm{O}$. The matrix ions included $\mathrm{Al}, \mathrm{Ba}, \mathrm{Be}, \mathrm{Bi}, \mathrm{Ca}, \mathrm{Cd}, \mathrm{Co}, \mathrm{Cu}, \mathrm{Fe}, \mathrm{Ga}, \mathrm{In}$, $\mathrm{Mg}, \mathrm{Mn}, \mathrm{Ni}, \mathrm{Pb}, \mathrm{Sc}, \mathrm{Sr}, \mathrm{Ti}, \mathrm{V}, \mathrm{Y}$, and $\mathrm{Zn}$. The solution $\mathrm{pH}$ was 7, the sample volume was $4 \mathrm{~mL}$, the flow rate was $0.2 \mathrm{~mL} \mathrm{~min}^{-1}$, and the elution solution consisted of $1 \mathrm{M} \mathrm{HNO}_{3}(2 \mathrm{~mL})+6 \mathrm{M} \mathrm{HNO}_{3}(1 \mathrm{~mL})+$ EPW $(1 \mathrm{~mL})(n=3)$.
} 
Table 3. Separation of metals from certified reference material BCR-713 (effluent wastewater).

\begin{tabular}{lllll}
\hline Certified data $^{\mathrm{a}}$ & & & \multicolumn{2}{l}{ This work } \\
\cline { 1 - 1 } Species & Value $\left(\mu \mathrm{g} \mathrm{L}^{-1}\right)$ & & Species & Value $\left(\mu \mathrm{g} \mathrm{L}^{-1}\right)$ \\
\cline { 1 - 1 } $\mathrm{As}$ & $9.7 \pm 1.1$ & & $\mathrm{As}(\mathrm{V})$ & $8.7 \pm 0.8$ \\
$\mathrm{Cd}$ & $5.1 \pm 0.6$ & & $\mathrm{Cd}(\mathrm{II})$ & $5.2 \pm 0.7$ \\
$\mathrm{Cr}$ & $21.9 \pm 2.4$ & & $\mathrm{Cr}(\mathrm{III})$ & $\mathrm{ND}^{\mathrm{b}}$ \\
$\mathrm{Pb}$ & $47 \pm 4$ & & $\mathrm{~Pb}(\mathrm{II})$ & $\mathrm{ND}^{\mathrm{b}}$ \\
$\mathrm{Se}$ & $5.6 \pm 1.0$ & & $\mathrm{Se}(\mathrm{IV})$ & $\mathrm{ND}^{\mathrm{b}}$ \\
\hline
\end{tabular}

${ }^{a}$ Certified by EC-JRC-IRMM (European Commission Joint Research Centre, Institute of Reference Materials and Measurements)

${ }^{\mathrm{b}} \mathrm{ND}=$ Not detected. 
Table 4. Separation of metals from spiked samples of 'real' waters and soil washing effluent.

\begin{tabular}{lllllll}
\hline Sample & & $A s(\mathrm{~V})$ & $\mathrm{Cd}(\mathrm{II})$ & $\mathrm{Cr}(\mathrm{III})$ & $\mathrm{Pb}(\mathrm{II})$ & $\mathrm{Se}(\mathrm{IV})$ \\
\cline { 2 - 6 } & Added $\left(\mu \mathrm{g} \mathrm{L}^{-1}\right)$ & 15.0 & 22.5 & 10.4 & 41.4 & 15.8 \\
\hline Tap Water & Found $\left(\mu \mathrm{g} \mathrm{L}^{-1}\right)$ & $14.9 \pm 0.3$ & $18.9 \pm 0.9$ & $10.5 \pm 1.5$ & $40.8 \pm 3.1$ & $15.9 \pm 1.2$ \\
& Recovery $(\%)$ & 99.4 & 83.9 & 101.1 & 98.3 & 100.4 \\
\hline River Water & Found $\left(\mu \mathrm{g} \mathrm{L}^{-1}\right)$ & $15.1 \pm 0.5$ & $22.8 \pm 0.7$ & $10.6 \pm 0.2$ & $41.6 \pm 0.8$ & $15.8 \pm 0.3$ \\
& Recovery (\%) & 100.6 & 101.5 & 101.9 & 100.3 & 100.0 \\
\hline Soil washing & Found $\left(\mu \mathrm{g} \mathrm{L}^{-1}\right)$ & $15.0 \pm 0.3$ & $22.5 \pm 0.9$ & $10.6 \pm 0.5$ & $41.5 \pm 0.9$ & $13.8 \pm 1.4$ \\
effluent & Recovery (\%) & 100.3 & 100.3 & 101.5 & 100.2 & 87.5 \\
\hline
\end{tabular}




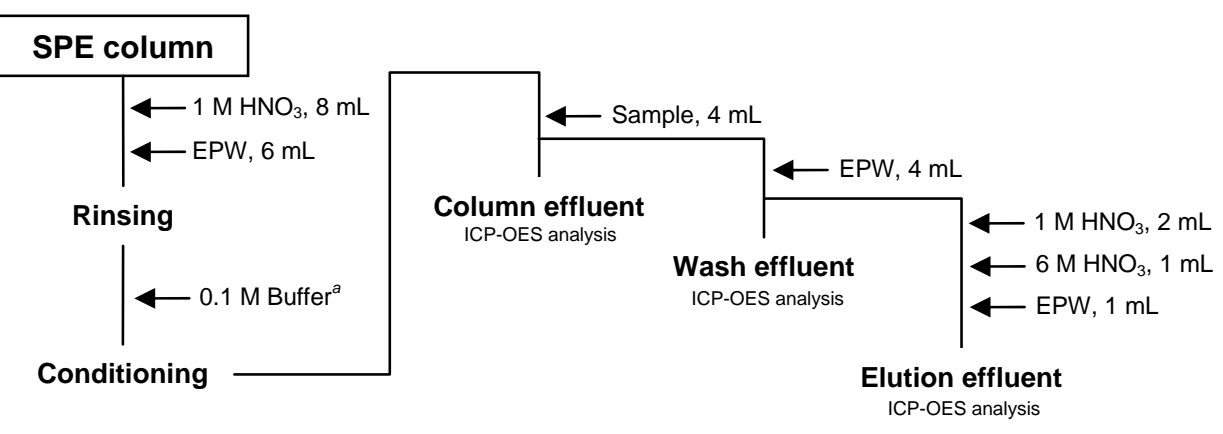

${ }^{a}$ 32 40 mL, MES buffer ( $\left.\mathrm{pH} 4-6\right)$, HEPES buffer ( $\left.\mathrm{pH} 7-8\right)$, TAPS buffer ( $\mathrm{pH}$ 9)

Fig. 1: Schematic workflow diagram of the separation process 
TE-01: AnaLig TE-01, C-100: Chelex-100, PA-1: NOBIAS Chelate PA-1, PB-1: NOBIAS Chelate PB-1, SA-1: NOBIAS Ion SA-1, SC-1: NOBIAS Ion SC-1
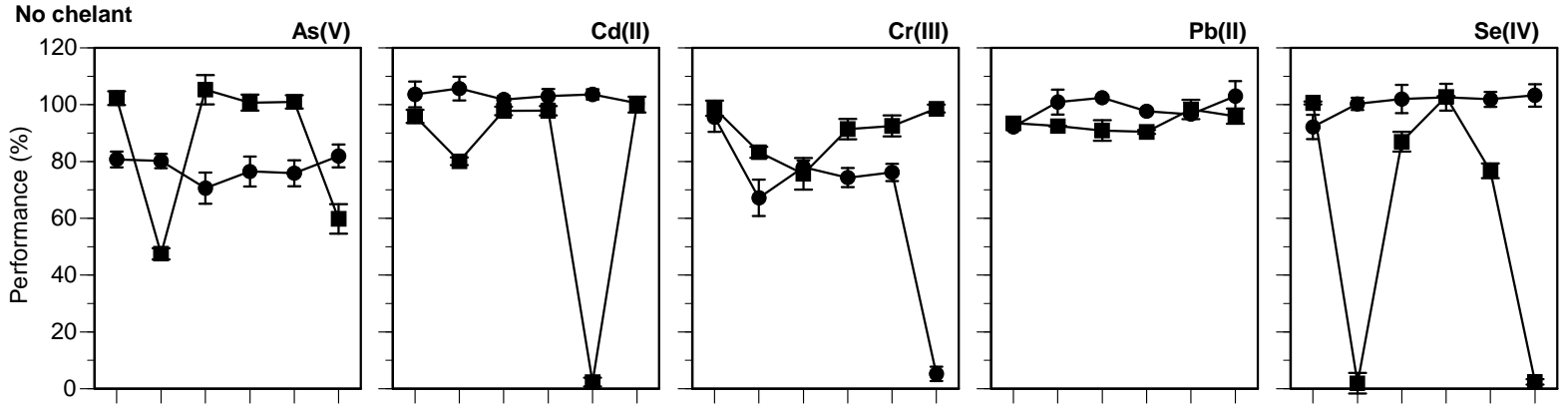

Chelant: NTA, nitrilotriacetic acid
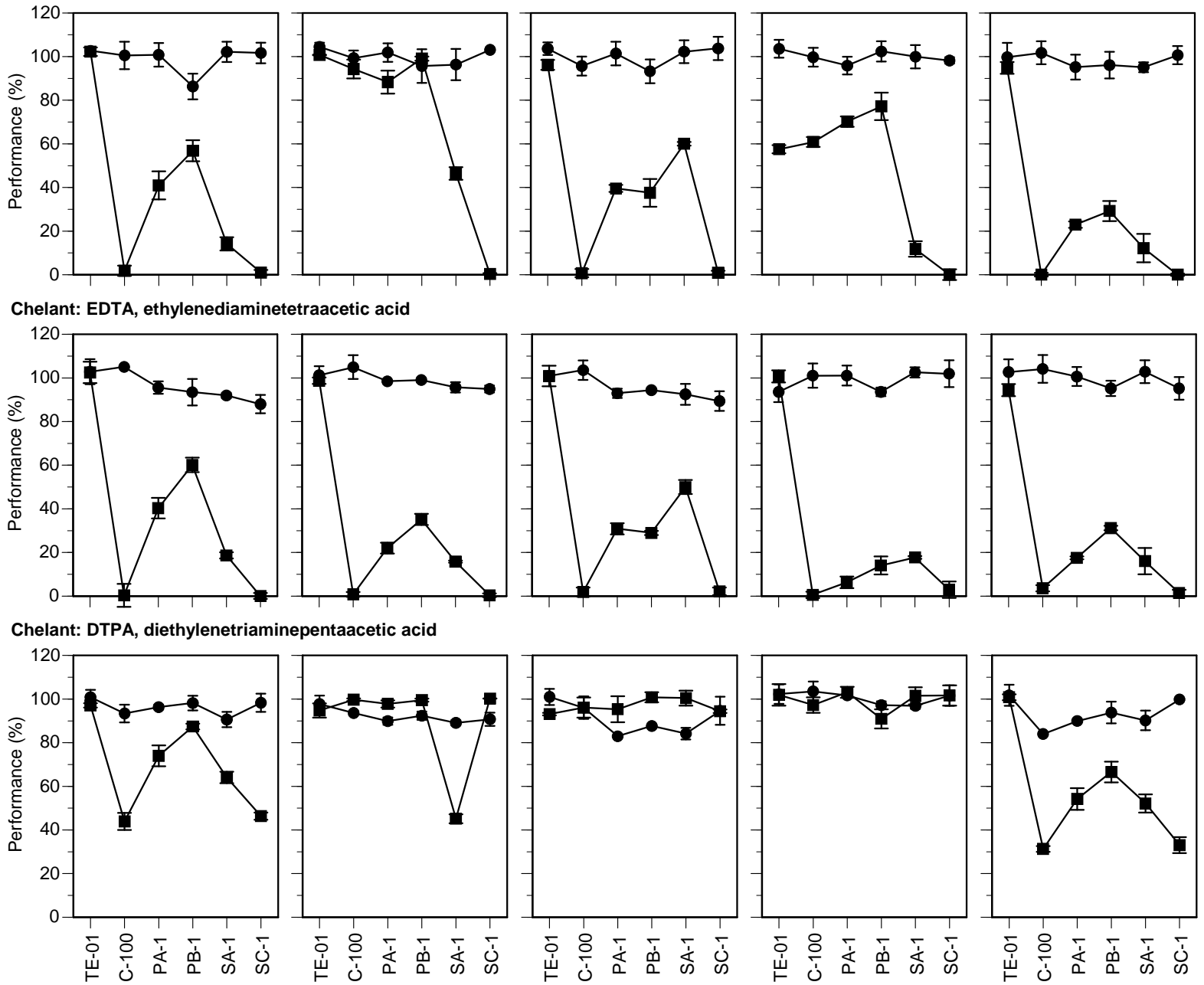

Fig. 2: Comparative performance of different SPE columns. The sample solutions were composed of $200 \mu \mathrm{M}$ As(V), Cd(II), Cr(III), Pb(II), or Se(IV). The chelant was $10 \mathrm{mM}$ NTA, EDTA, DTPA or EDDS and the matrix was $\mathrm{H}_{2} \mathrm{O}$. The solution $\mathrm{pH}$ was 7, the sample volume was $4 \mathrm{~mL}$, the flow rate was $0.2 \mathrm{~mL} \mathrm{~min}{ }^{-1}$, and the elution solution consisted of $1 \mathrm{M} \mathrm{HNO}_{3}(2$ $\mathrm{mL})+6 \mathrm{M} \mathrm{HNO}_{3}(1 \mathrm{~mL})+\mathrm{EPW}(1 \mathrm{~mL})(n=3)$. 


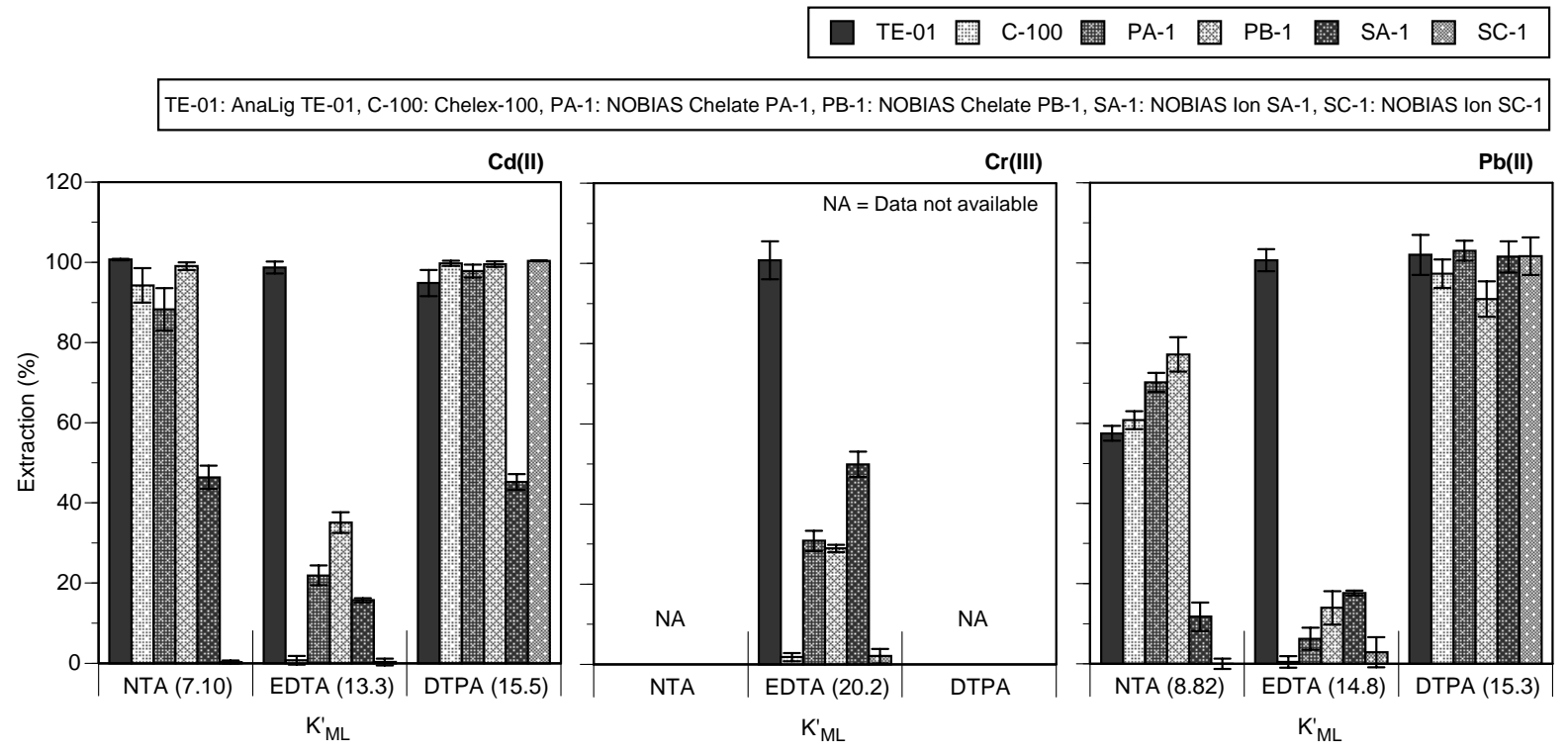

Fig. 3: Effect of metal-chelant stability constants on the performance of SPE materials. The sample solutions were composed of $200 \mu \mathrm{M} \mathrm{Cd}(\mathrm{II}), \mathrm{Cr}(\mathrm{III})$ or $\mathrm{Pb}(\mathrm{II})$, and the chelant was 10 mM NTA, EDTA or DTPA. The matrix was $\mathrm{H}_{2} \mathrm{O}$, the solution $\mathrm{pH}$ was 7 , the sample volume was $4 \mathrm{~mL}$, the flow rate was $0.2 \mathrm{~mL} \mathrm{~min}$, and the elution solution consisted of $1 \mathrm{M} \mathrm{HNO}_{3}(2$ $\mathrm{mL})+6 \mathrm{M} \mathrm{HNO}_{3}(1 \mathrm{~mL})+\operatorname{EPW}(1 \mathrm{~mL})(n=3)$. 


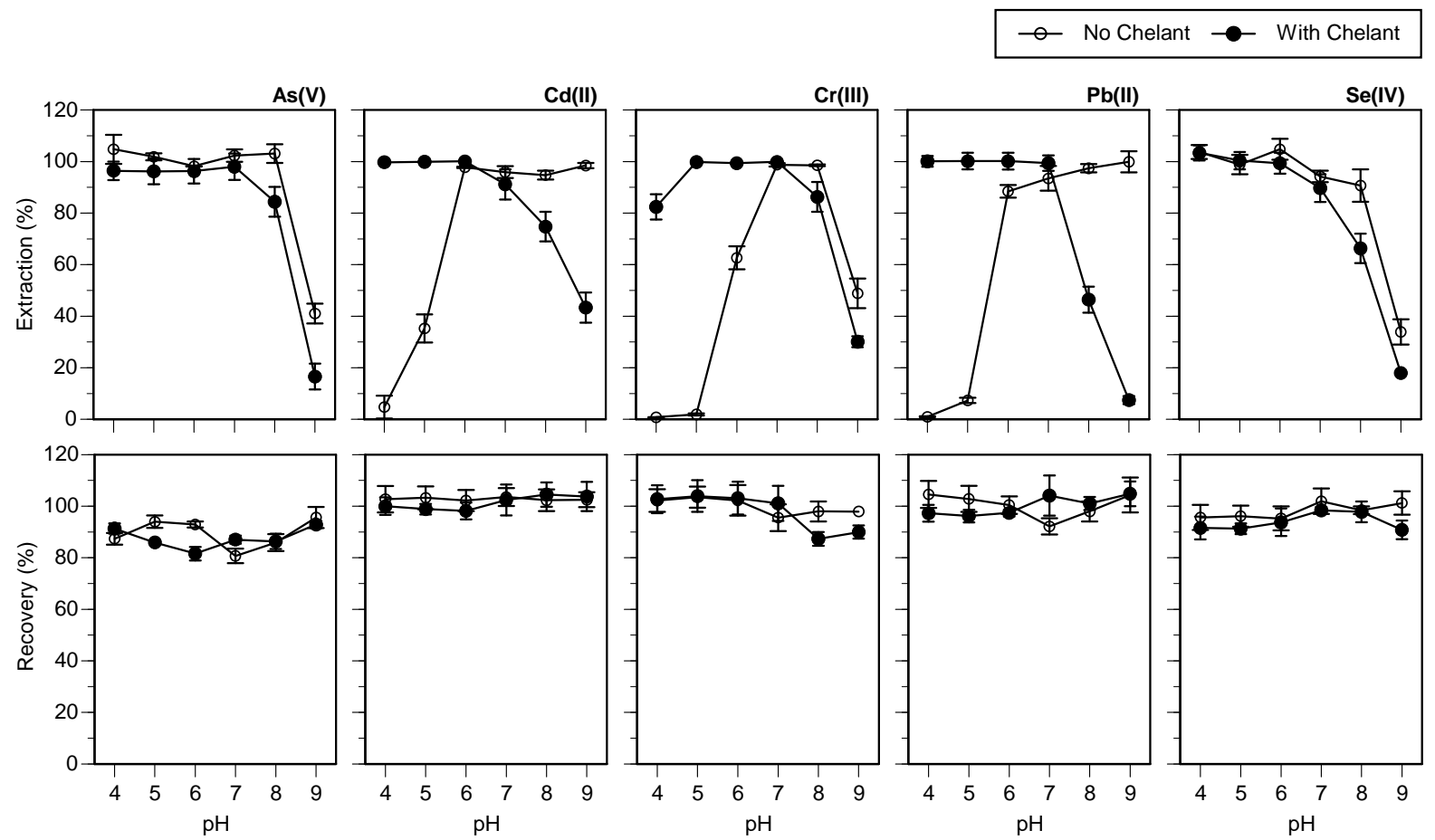

Fig. 4: Extraction and recovery performance of the MRT-SPE column as a function of $\mathrm{pH}$, with or without chelant. The sample solutions were composed of $200 \mu \mathrm{M} \mathrm{As}(\mathrm{V}), \mathrm{Cd}(\mathrm{II})$, $\mathrm{Cr}(\mathrm{III}), \mathrm{Pb}(\mathrm{II})$, or $\mathrm{Se}(\mathrm{IV})$. The chelant was $10 \mathrm{mM}$ EDTA, and the matrix was $\mathrm{H}_{2} \mathrm{O}$. The $\mathrm{pH}$ ranged from 4 to 9 , the sample volume was $4 \mathrm{~mL}$, the flow rate was $0.2 \mathrm{~mL} \mathrm{~min}^{-1}$, and the elution solution consisted of $1 \mathrm{M} \mathrm{HNO}_{3}(2 \mathrm{~mL})+6 \mathrm{M} \mathrm{HNO}_{3}(1 \mathrm{~mL})+\mathrm{EPW}(1 \mathrm{~mL})(n=3)$. 

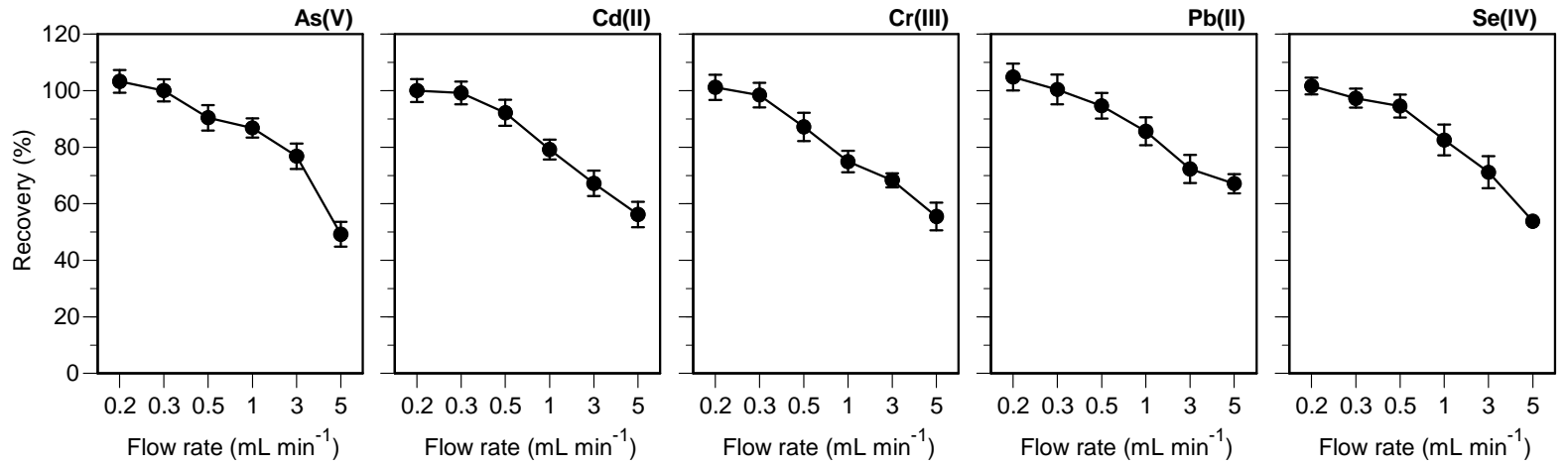

Fig. 5: Effect of sample loading flow rates on the separation performance of the MRT-SPE column. The sample solutions were composed of $200 \mu \mathrm{M} \mathrm{As}(\mathrm{V}), \mathrm{Cd}(\mathrm{II}), \mathrm{Cr}(\mathrm{III}), \mathrm{Pb}(\mathrm{II})$, or Se(IV). The chelant was $10 \mathrm{mM}$ EDTA, and the matrix was $\mathrm{H}_{2} \mathrm{O}$. The $\mathrm{pH}$ was 7 , the sample volume was $4 \mathrm{~mL}$, the flow rate ranged from $0.2-5 \mathrm{~mL} \min ^{-1}$, and the elution solution consisted of $1 \mathrm{M} \mathrm{HNO}_{3}(2 \mathrm{~mL})+6 \mathrm{M} \mathrm{HNO}_{3}(1 \mathrm{~mL})+\mathrm{EPW}(1 \mathrm{~mL})(n=3)$. 

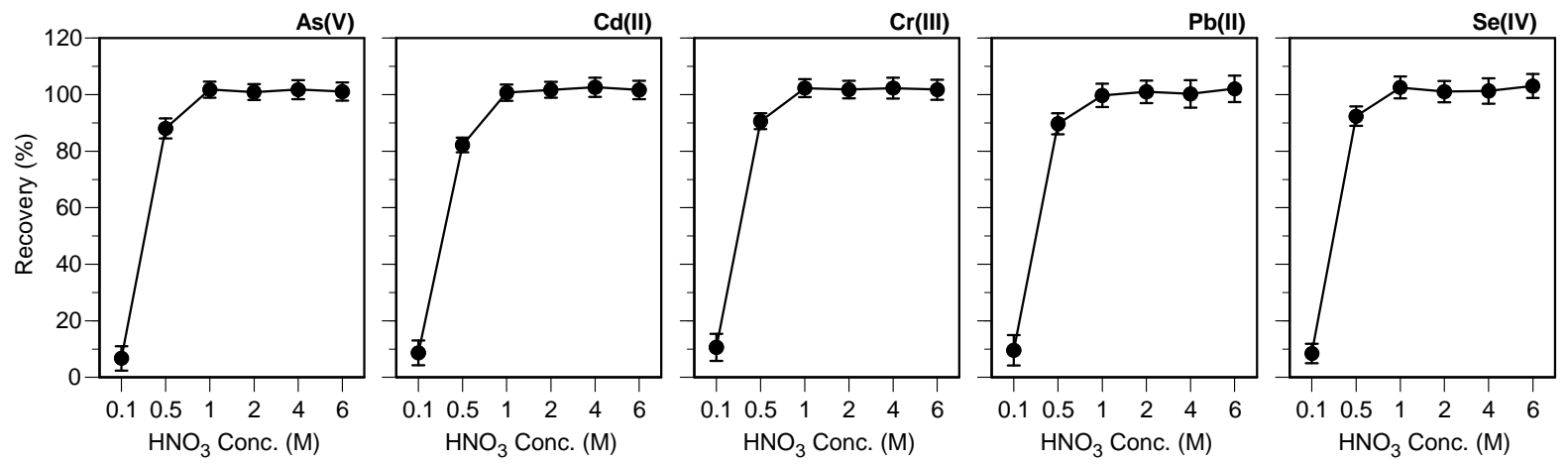

Fig. 6: Effect of eluent concentration on the separation performance of the MRT-SPE column. The sample solutions were composed of $200 \mu \mathrm{M} \mathrm{As}(\mathrm{V}), \mathrm{Cd}(\mathrm{II}), \mathrm{Cr}(\mathrm{III}), \mathrm{Pb}(\mathrm{II})$, or $\mathrm{Se}(\mathrm{IV})$. The chelant was $10 \mathrm{mM}$ EDTA, and the matrix was $\mathrm{H}_{2} \mathrm{O}$. The solution $\mathrm{pH}$ was 7 , the sample volume was $4 \mathrm{~mL}$, the flow rate was $0.2 \mathrm{~mL} \mathrm{~min}^{-1}$, and the elution solution consisted of $0.1-$ $6 \mathrm{M} \mathrm{HNO}_{3}(3 \mathrm{~mL})+\mathrm{EPW}(1 \mathrm{~mL})(n=3)$. 